\title{
ТЭТГЭВЭР ТОГТООЛГОХ НАСЫГ ОНОВЧТОЙ БОЛГОХ ЭДИЙН ЗАСГИЙН ЗАРИМ АСУУДАЛ
}

\author{
Х.Бумдэлгэр \\ МҮИС-ийн ЭЗБУС \\ Kh.buma@yahoo.com
}

\section{ХУРААНГУЙ}

СүҮлийн жилүүдэд хүн амын дундаж наслалт нэмэгдэж, тэтгэврийн насны хүний хувийн жин өсөхийн хамт ажиллагсдын тоо буурах хандлага бий болж тэтгэврийн сангийн санхүҮжилтэнд сөрөг асуудлууд Үүсгэх шалтгаан болж байна. Эдгээр асуудлуудын дотроос тэтгэвэр тогтоолгох хуулийн насыг хүний дундаж наслалт болон тэтгэврийн даатгалын санд хуримтлуулах хөрөнгийн хэмжээтэй уялдуулан тогтоох асуудал багтаж байгаа юм.

ТYЛХУУР ҮГ: Тэтгэврийн нас, дундаж наслалт, хөгшрөлтийн физиологи, нөхөн олговрын индексжүүлэлт

\section{ОРШИЛ}

Монгол улс эртний уламжлалтай орны хувьд нийгмийн халамж, хамгааллын асуудлыг эрхэмлэн сахиж ирсэн түүхтэй. Эртнээс ахмадууд, өнчин ядуусыг тэтгэх үйлсийг төрийн бодлогын хэмжээнд тавьж ирсэн тухай түүхийн баримт, бичгүүдэд тэмдэглэгдсэн байна. ${ }^{1}$ Дэлхийн бусад орнуудтай харьцуулахад, Монгол улс дундаж наслалт багатай, тэр хэмжээгээрээ тэтгэвэр тогтоолгох хуулийн нас эрт, тэтгэвэр тогтоолгосноос хойш амьдрах хугацаа богинотой орны тоонд багтаж байна.

Өндөр насны тэтгэвэр бол хүний хөгшрөлтийн биологийн үйл явцтай холбоотой эдийн засаг, нийгмийн чухал асуудал юм. Монгол улсад тэтгэвэр тогтоолгох хуулийн насыг нийгмийн чиг баримжаа бүхий эдийн засгийн социалист тогтолцооны үед бусад социалист орноор баримжаалан 40-50 жилийн өмнө тогтоожээ.

\section{ХЭРЭГЛЭГДЭХУУН, АРГА ЗУЙ}

Судалгааны ажилд танин мэдэхүйн түгээмэл аргууд болон эдийн засаг, математик, статистикийн уламжлалт аргууд, регресийн тэгшитгэл, корреляци, түүвэрлэлт шинжилгээний аргуудыг ашигласан. Тэтгэвэр тогтоолгох нас, тэтгэврийн даатгалын өнөөгийн төлөв байдлыг судлахдаа хүснэгт, зураг, дүрслэл, шинжилгээ, таамаглал, синтиз, анализ, индукци, дедукци аргыг, тэтгэвэр тогтоолгох насанд нөлөөлөх хүчин зүйлсийн өөрчлөлтийг корреляци, регрессийн шинжилгээний аргыг хэрэглэсэн тооцсон.

\section{СУДАЛГААНЫ АЖЛЫН ҮР ДҮН}

Монгол улсын тэтгэвэр тогтоолгох хуулийн нас зохистой тогтоогдсон эсэх, ямар хэмжээнд байвал тохиромжтой болохыг тогтоох зорилгоор дэлхийн 40 орны хүн амын насжилт ба тэтгэвэр тогтоолгох хуулийн насыг хүйс бүрээр зэрэгцүүлж судлав.

\footnotetext{
${ }^{1}$ Настояшее и будушее правовой научно государственной Германии
} 


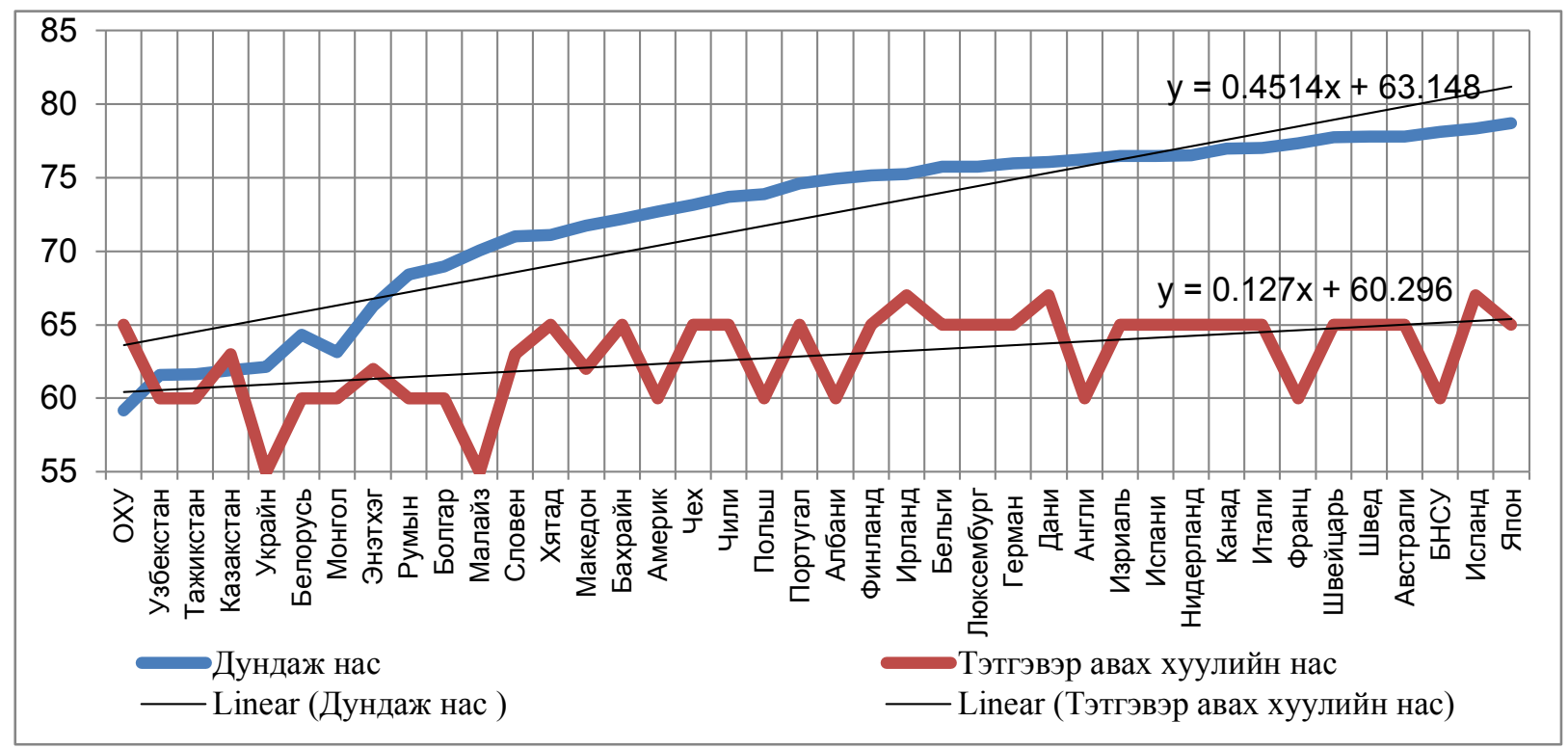

График №1. Эрэгтэй хүн амын дундаж наслалт ба тэтгэврийн насыг улс орнуудаар зэрэгцүүлсэн судалгаа

Дээрхи графикаас харахад, хуучин социалист орнуудад харьцангуй доогуур бөгөөд эрэгтэйчүүд эмэгтэйчүүдээс бага насалж байхад эдийн засгийн өндөр хөгжилтэй орнуудад насжилтын түвшин өндөр, эрэгтэй эмэгтэйчүүдийн насны зөрүү бага байв. Япон хүмүүсийн дундаж наслалт хамгийн өндөр байгаа бөгөөд тэд дунджаар эрэгтэй 78,73 наслаж байна. Энэ нь тухайн улсын онцлог, хөгжил, тэтгэврийн даатгалын шимтгэл төлөх хувь хэмжээ, эдийн засгийн чадавхиас хамаарч байгаа юм.

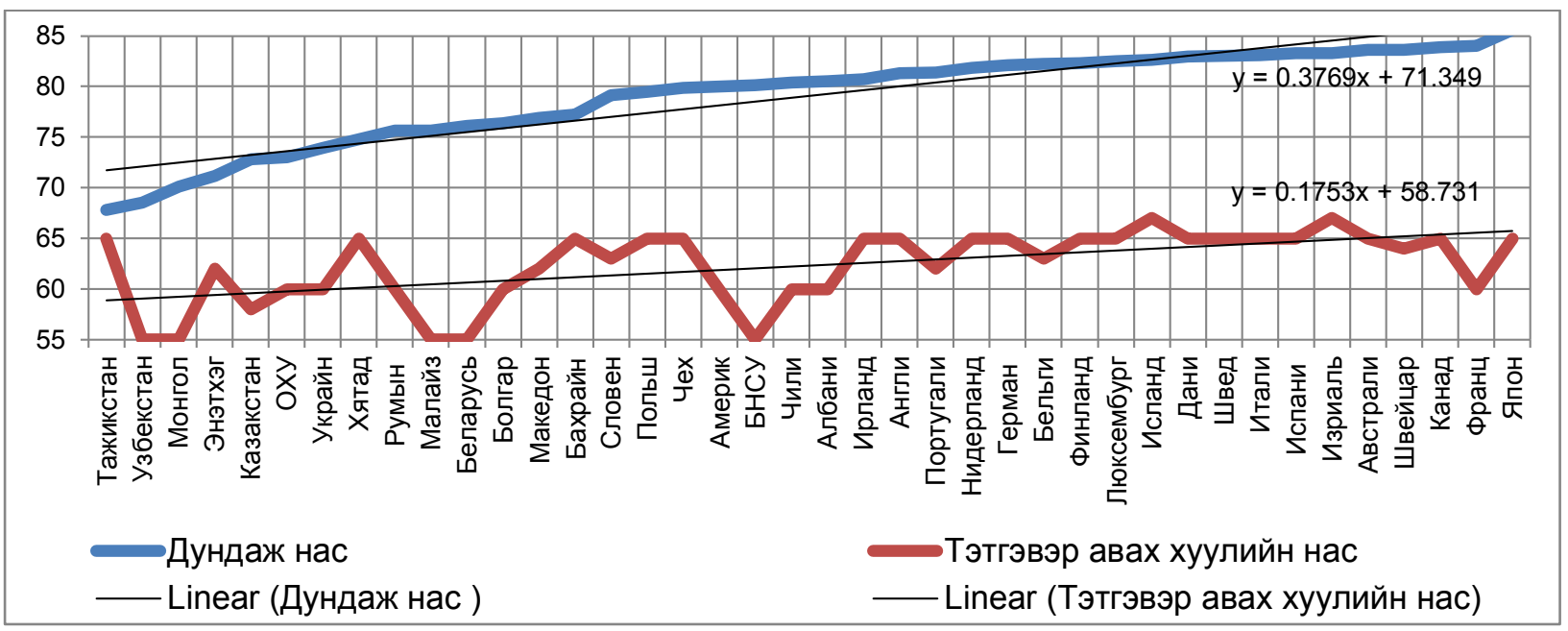

График №2. Эмэгтэй хүн амын дундаж наслалт ба тэтгэврийн насыг улс орнуудаар зэрэгцүүлсэн судалгаа

Хүмүүсийн амьдрах чадвар нь даатгуулагчийн нас, хөдөлмөрийн чадвар алдалт, эрүүл мэндээс шалтгаалсан эрсдэлийн хэмжээтэй холбоотой байдаг нь харагдаж байна. Мөн биологийн дундаж нас тэтгэвэр авах хуулийн нас нь хоорондоо сул хамааралтай байв. Судалгаанаас үзвэл, тэтгэвэр авах нас ба дундаж насны хоорондын хамаарлын корреляцын коэффициент эрэгтэй хүнийх $\mathrm{R}=0.49298$, эмэгтэй хүнийх $\mathrm{R}=0.51298$ байгаа нь дан ганц хүний дундаж насаар тодорхойлдоггүй гэдгийг харуулж байна. 


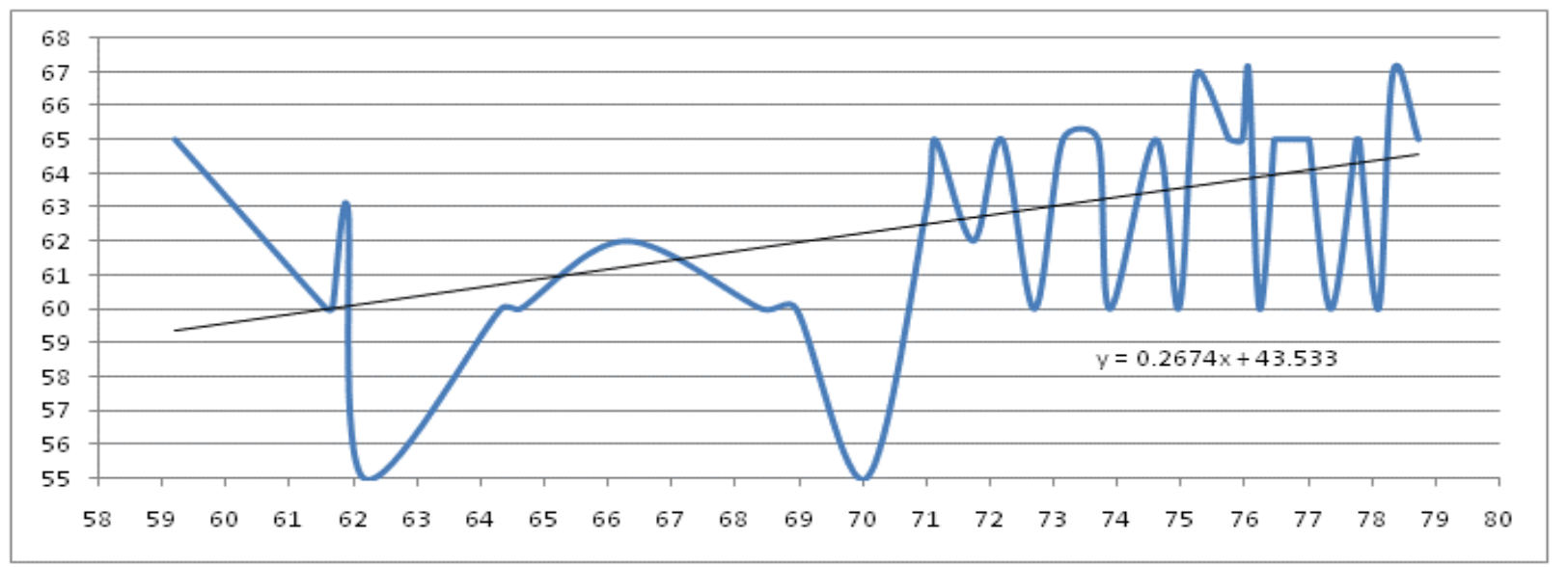

График №3. Эрэгтэйчүүдийн дундаж нас ба тэтгэврийн насны хамаарал

Судалгаанаас үзвэл, дундаж нас нэгээр нэмэгдэхэд эрэгтэйчүүдийн тэтгэврийн нас 0.2674-өөр нэмэгдэх зүй тогтол ажиглагдаж байна. Мөн үүнээс гадна хүн амын хүйсийн ялгаатай холбоотой болох нь дээрхи графикаас харагдаж байна. Иймд нийгмийн хамгаалал тэтгэвэр тэтгэмжийн асуудлыг шийдвэрлэхэд хүн амын хүйсийн асуудлыг гарцаагүй харгалзан үзэх шаардлагатай юм.

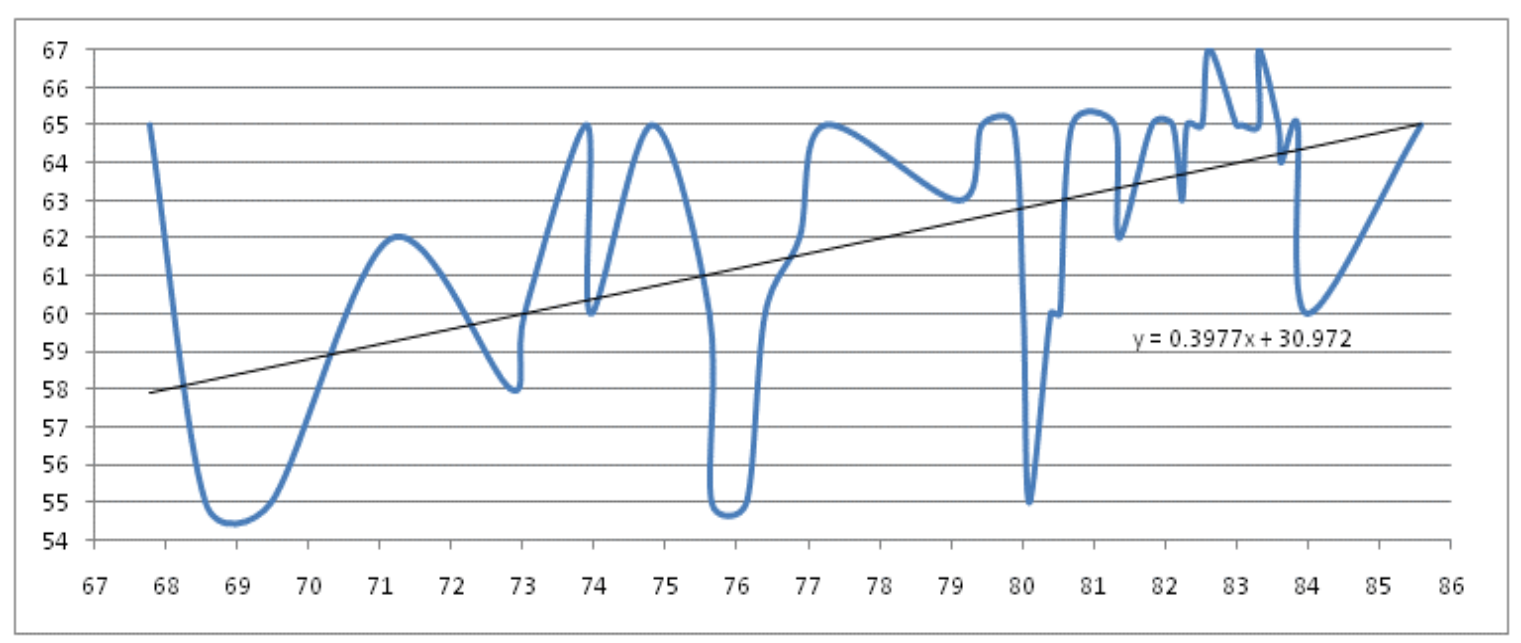

График №4. Эмэгтэйчүүдийн дундаж нас ба тэтгэврийн насны хамаарал

Судалгаанаас үзвэл, дундаж нас нэгээр нэмэгдэхэд эмэгтэйчүүдийнх 0,3977-оор нэмэгдэх зүй тогтол харагдаж байна. Энэхүу хүйсийн зөрүу нь эмэгтэйчүүдийн тэтгэвэр тогтоолгох насыг эрэгтэйчүүдийнхээс харьцангуй хатуу тогтоосныг харуулж байгаа үзүүлэлт юм.

\section{ШУУН ХЭЛЭЛЦЭХУЙ}

Тэтгэвэр тогтоолгох насыг олон жилийн өмнө хүний дундаж нас харьцангуй богино байх үед тогтоож, түүнээс хойш өөрчлөлт оруулаагүй, тэтгэврийн санд хуримталж байгаa хөрөнгийн хэмжээ багаас тэтгэврийг нэмэгдүүлэх боломжгүй байгаa зэрэг нь Монгол улсад тэтгэврийн насыг хянаж үзэх зайлшгүй шаардлагыг бий болгож байна.

Судалгаанаас үзвэл, тэтгэвэр тогтоолгох нас ба дундаж насны хоорондын хамаарлын корреляцын коэффициент: Эрэгтэй хүнийх $\mathrm{R}=0.49298$
Манай улсын хувьд, хүн амын дундаж наслалт дэлхийн өндөр хөгжилтэй улс орнуудын дунджаас нилээд доогуур боловч тэтгэвэр тогтоолгох нас эмэгтэйчүүдэд 55 , эрэгтэйчүүдэд 60 байгаa нь харьцангуй өндөр үзүүлэлт юм.

Регрессийн тэгшитгэл: $\mathrm{y}=0.2654 \mathrm{x}+43.685$

Эмэгтэй хүнийх $\mathrm{R}=0.51298$

Регрессийн тэгшитгэл: $\mathrm{y}=0.431 \mathrm{x}+28.247$ байна.

Тэтгэврийн насыг өндөрсгөх боломжийг илрүүлэхийн тулд хүн амын наслалт тэтгэврийн насны хоорондын хамаарлын регрессийн тэгшитгэл ба Монгол улсын хүн амын дундаж насны прогноз /YCX-оос тооцсон 2000 оны хүн амын тоо, 2007 онд хийсэн тодотголыг ашиглан/-д тулгуурлан дараах тооцоог хийв. 
Биологийн насанд тулгуурлан тооцсон тэтгэвэр тогтоох нас

\begin{tabular}{lcccc}
\hline \multicolumn{3}{c}{ Эрэгтэй } & \multicolumn{3}{c}{ Эмэгтэй } \\
\hline Он & $\begin{array}{c}\text { Дундаж } \\
\text { насны } \\
\text { прогно3 }\end{array}$ & $\begin{array}{c}\text { Тэтгэвэр тогтоох } \\
\text { насыг нэмэх боломж }\end{array}$ & $\begin{array}{c}\text { Дундаж насны } \\
\text { Прогно3 }\end{array}$ & $\begin{array}{c}\text { Тэтгэвр тогтоох насыг } \\
\text { нэмэх боломж }\end{array}$ \\
2012 & 63.36 & & 72.42 & 59.8 \\
2017 & 64.53 & 60.5 & 75.31 & 60.9 \\
2022 & 65.7 & 60.8 & 78.19 & 62.1 \\
2027 & 66.88 & 61.1 & 80.07 & 62.8 \\
2032 & 68.05 & 61.4 & 83.96 & 64.4 \\
\hline
\end{tabular}

Тооцооноос Үзвэл, эрэгтэйчүүдийн тэтгвэр тогтоолгох насыг 2022 он хүртэл хөндөх боломжгүй, 2032 оноос 62 хүргэх, харин эмэгтэйчүүдийнхийг ойрын хугацаанд 60 нас, 2032 оноос 64 нас хүргэх боломжтой байна.

\section{ДҮГНЭЛТ}

Хүн амын олонхи нь ядуу, аж ахуй нэгж, байгууллагын төлбөрийн чадвар муу, иргэд даатгалын Үүрэг ач холбогдлыг бүрэн гүйцэд ухаарахгүй байгаа зэргээс шалтгаалан Монгол улсад тэтгэврийн даатгалын харилцаа зах зээлийн нөхцөлд байх тэр хэмжээнд төлөвшиж чадаагүй байна.

Дэлхийн бусад орнуудтай харьцуулахад, Монгол улс насжилт багатай, тэтгэвэр тогтоолгох хуулийн нас эрт, тэтгэвэр тогтоолгосноос хойш амьдрах хугацаа богинотой орны тоонд багтаж байна. Тэтгэвэр тогтоолгох хуулийн насыг тогтооход хүний биологийн нас, улс орны эдийн засгийн хөгжил, тэтгэврийн сангийн тогтолцоо ихээхэн үүрэгтэй.

Монгол улсын тэтгэврийн санд жил тутамд хуримтлагдаж байгаа хөрөнгийн хэмжээ нь тэтгэвэр авагчдад төлж байгаa хөрөнгийг нөхөж хүрэхгүй, улсын төсвөөр санхүүжиж байгаа бөгөөд цаашид тэтгэвэрт төлөх улсын төсвийн санхүүжилт эрс нэмэгдэхээр байгаа нь тэтгэврийн даатгалыг хямралд хүргэх магадлалтай байна. Тэтгэврийн даатгалын сангийн хөрөнгө нь ажил олгогч даатгуулагчдаас бүрдүүлсэн хуримтлал бөгөөд энэ хуримтлалын чөлөөт хэсгийг даатгалын байгууллага эргэлтэнд оруулан өсгөх бодлого барьж ажиллах нь зүйтэй.
Тэтгэвэр тогтоолгох насыг өөрчлөхийн хамт тэтгэврийн даатгалын хуримтлалын аргад шилжих, суурь ба орлогоос хамаарах тэтгэвэр, олон шатлалт тэтгэвэр бий болгох, нийгмийн даатгалыг хувийн хэвшилд шилжүүлэх зэрэг тогтолцооны өөрчлөлт хийх шаардлагатай юм.

\section{НОМ ЗYЙ}

1. “Нийгмийн даатгалын багц хуулиуд” тэдгээрт нийцүүлэн гаргасан тогтоол, шийдвэрүүд, 1994 $\mathrm{OH}$

2. "Нийгмийн даатгалын сангаaс олгох тэтгэвэр тэтгэмжийн тухай хууль”, 1994 он

3. “Төрөөс тэтгэврийн шинэчлэлийн талаар 2021 он хүртэл баримтлах үндсэн чиглэл”, 2010 он

4. “Тэтгэврийн даатгалын шимтгэлийн нэрийн дансны тухай”, Монгол улсын хууль 1999 он

5. Далхжав. Д, “Нийгмийн даатгалын сангийн санхүүгийн удирдлагыг боловсронгуй болгох зарим асуудал" докторын зэрэг горилсон нэг сэдэвт бүтээл, 2008 он

6. Дагвадорж. Ч, “Нийгмийн хамгаалал /онол арга зүйн туршлага, харьцуулалт “, 2010 он

7. "Нийгмийн даатгалын салбарын хөгжил, тулгамдсан асуудлууд”, 2007 он,УНДЕГ

8. Кристтофер, Бендэр “Тэтгэврийн шинэчлэл”, 2007 $\mathrm{OH}$

9. “Монголын залуучуудын хөдөлмөр эрхлэлтийн өнөөгийн байдал”, Үндэсний илтгэл, 2006 он

10. Монгол улсын Статистикийн эмхэтгэл, $2011 \mathrm{oH}$

11. "Настоящее и будущее правовой научногосударственной Германии"

12. U.S.Social Security Administration, "Social Security Programs Throughout the World", 1999 oH

13. www. mswc.pmis.gov.mn

14. www.socialsecurity.fgov.be/faofat/

15. www.kokuho.or.jp

16. www.inss.gov.br,www.social 


\section{SOME ECONOMIC ISSUES OF OPTIMIZATION OF RETIRING AGE}

Many factors such as economic effort, living age of population, quantity of property collection in fund, way of paying out pension, collection of property in fund influence for stabilizing age of retiring. Thus, I had considered the issue about stabilizing retiring age according to the law, connected with living age of population and establishment of pension fund. According to the research, age of population, relation between legal age of stabilizing pension and average living age, it shows that it is impossible to provoke men's age of stabilizing pension but for woman 60 recent times, after 2032 it is possible to reach 64. 